\title{
Local wisdom in environment conservation: A study on a conservation and energy self-sufficient village
}

\section{Kearifan lokal dalam konservasi lingkungan: Studi pada desa konservasi dan mandiri energi}

\author{
Fandi Sudiasmo* \& Novi Catur Muspita
}

Department of Sociology, Faculty of Social and Political Sciences, Universitas Islam Balitar Address: Jalan Majapahit 2-4, Sananwetan, Blitar, East Java 66137

E-mail: fandisudiasmo@gmail.com

Article History: Received 8 November 2019; Accepted 2 November 2020; Published Online 15 December 2020

\begin{abstract}
Farmer group of Bendrong Hamlet has conducted a series of reforestation activities to cope with landslides and secure the clean water supply to all villages. Although the attempt has run well, many problems have begun to arise, such as people's land being sold. The buyers are outsiders, thereby deviating from the specified principles of conservation and people's awareness of conservation activity decreasing. These problems should be solved immediately, recalling Malang Regency is vulnerable to landslide disaster incidence. The research objectives were to reconstruct the conservation conceptualization model and improve the community-based conservation model using a qualitative research method with a case study approach and interactive data analysis technique. The conservation undertaken by people in Bendrong Hamlet divides into two: green and energy conservations. Green conservation conduct through people planting forests with forestry plants and agroforestry plants below it - energy conservation conduct by processing cow manure into biogas as alternative energy. Besides, the conservation activity is intended to be intended for environmental factors and intended as an economic factor obtained from green and energy conservation activities. Social institutions' participation, legitimacy, and government, private, and community's participation, either individually or in the group, are essential to the performance of conservation activity as the attempt of conserving natural resource; also, economic activity should be included in the conservation activity to result in an effective and sustainable community conservation activity.
\end{abstract}

Keywords: community-based conservation; legitimacy; local wisdom

\begin{abstract}
Abstrak
Kelompok tani Dusun Bendrong melaksanakan serangkaian kegiatan penghijauan dalam upaya menanggulangi longsor dan menjamin pasokan air bersih bagi seluruh desa. Sekalipun upaya tersebut sudah berjalan baik, namun berbagai permasalahan mulai bermunculan, diantaranya lahan masyarakat sudah banyak terjual dan pembelinya orang luar daerah sehingga menyimpang dari prinsip-prinsip konservasi yang sudah ditetapkan, selain itu kesadaran masyarakat menurun dalam kegiatan konservasi, hal ini tentu harus segera dibenahi mengingat Kabupaten Malang kritis terhadap kejadian bencana longsor. Tujuan penelitian untuk merekonstruksi model konseptualisasi konservasi dan perbaikan model konservasi berbasis masyarakat, menggunakan metode penelitian kualitatif dengan pendekatan studi kasus dan teknik analisis data Interaktif. Konservasi yang dijalankan masyarakat di Dusun Bendrong terbagi ke dalam dua kegiatan, yakni konservasi hijau dan konservasi energi. Konservasi Hijau dengan kegiatan penanaman hutan rakyat dengan tanaman kehutanan dan di bawahnya tanaman agroforestri. Konservasi energi yakni menjadikan kotoran sapi diubah menjadi biogas sebagai energi alternatif. Kegiatan konservasi disini, selain untuk faktor lingkungan juga sebagai faktor ekonomi yang diperoleh dari kegiatan konservasi hijau dan konservasi energi. Keterlibatan institusi sosial, legitimasi, dan partisipasi dari pemerintah, swasta, juga masyarakat baik secara perorangan maupun kelompok sangatlah penting dalam berjalannya kegiatan konservasi sebagai upaya pelestarian sumber daya alam, selain itu keterkaitan kegiatan ekonomi harus dimasukkan dalam kegiatan konservasi guna efektifnya kegiatan konservasi masyarakat yang berkelanjutan.
\end{abstract}

Kata kunci: konservasi berbasis masyarakat; legitimasi; kearifan lokal 


\section{Introduction}

In the attempt to prevent an environmental crisis, conservation should get serious attention, particularly concerning landslide disaster. From May to December 2019, landslide disaster incidence increased dramatically (Nana 2017) from 18 incidences from the beginning of the year through April to 192 incidences with 14 landslide cases up to December 2019, with total damage and loss of 6.164.069.500 IDR (Badan Penanggulangan Bencana Daerah 2017). It is interesting to study more in-depth the conservation attempt taken in Bendrong Hamlet, Malang Regency. The natural conservation practices have been existing and developing within society, in the form of custom and cultural local wisdom and imitation and innovation made by local conservation heroes (Wardani 2017).

Farmer group of Bendrong Hamlet has conducted a series of reforestation activities to cope with landslides and secure the clean water supply to all villages. About 300 ha-wide forests and land have been planted with perennial plants. Through the Community-Based Forest Management Program or Pengelolaan Hutan Bersama Masyarakat (PHBM) and Perum Perhutani, the farmer group of Bendrong Hamlet has also developed cattle food green plants to reduce the dependency on the green plant in the forest (Hakim \& Wienarto 2010). Although the attempt has run well, many problems have begun to arise such as people's land has been sold, and the buyers are outsiders, thereby deviating from the specified principles of conservation, in addition to people's awareness of conservation activity decreasing. These problems should be solved immediately, recalling Malang Regency is vulnerable to landslide disaster incidence.

A previous study by Sudiasmo (2017) found that people's awareness became the primary matter in conservation activity; however, owing to the attempt taken by an agent, conservation activity has been done successfully. Conservation activity is conducted as the manifestation of religious value implementation and cares about environment inseparable from the inspiration of Al-Qur'an verses Q.S Al Isra (17):44, what has been done is considered as worship, to give alms through seed, with the principle of sincerity, how we should be sincere based on religion guidance, the plant with heart, consider the plant as ourselves, and improve the human resource. Previous studies can be the reference in the research to achieve a community-based conservation model recalling the similar problems encountered.

In the current research, conservation focuses on local wisdom values. Prodanciuc (2012) considered social institution as a formal organizational structure (an activity based on norm system building on tradition or elaborated intentionally) that the human group or human community makes briefly based on need, functioning as a means of getting superior efficiency level in its relation to production activity, material, and spiritual values. In conclusion, a social institution is a norm system, value, status, role, a persistent internal group of individuals, regulatory principle, and culture governing behavior to meet some of humans' repeated, basic needs. A social institution is an integral part of society's culture in the form of local wisdom. According to Maridi (2015) the form of local wisdom can be value, norm, belief, and special rules. The functions of local wisdom include 1) natural resource conservation and preservation, 2) human resource development, 3) cultural and science development, and 4) instruction about religious advice, belief, letter, and prohibition. Local wisdom in conservation activity is essential to undertake in order to maintain the function of local wisdom.

The research problem is how the existing community-based environment conservation model is in conservation and energy self-sufficient village in Bendrong Hamlet, aiming to reconstruct the conservation conceptualization model and improve the community-based conservation model. The advantage of this model is that it is a conservation model approach giving the people living around the conservation area an opportunity of participating actively in the attempt of the processing conservation area, building environment-conscious community, and preventing environment and economic value crisis as an act of mitigating the effect of climate change. 


\section{Research Method}

This study's research method was a qualitative one with a case study, aiming to reconstruct the conservation conceptualization and improve the community-based conservation model to prevent the environmental crisis. This research was conducted in Bendrong Hamlet, Argosari Village, Jabung Sub-District, Malang Regency, a conservation and energy-self sufficient village which undertaking environment conservation practice. Through this research, a representation expects to be obtained related to developing a community-based conservation model. The research was conducted in 2019 and the subject of research was selected purposively, consisting of actors in conservation activity, such as chairperson and members of farmer group: Taruna Tani, Paguyuban Bakti Manunggal (PBM), Environment-Care Women Group or Kelompok Perempuan Peduli Lingkungan (KPPL), Female Farmer Group or Kelompok Tani Wanita. People participating directly in conservation activity in the village, and 17 people were interviewed.

Interview, observation, documentation, and forum group discussion are used to obtain data related to how the local wisdom values have been implemented in conservation activity, explore the people's perspective and stance during participation, and the reason for their participation and future expectations of the activity. The interactive technique of analyzing data used in this study was proposed by Miles and Haberman through four stages: data collection, data reduction, data display, and conclusion drawing (Sugiyono 2008). The data obtained related to local wisdom, public participation, social institution participation, supporting legitimacy, and natural resource conservation as the conservation effort. These were then described to obtain the data powerfully relevant to the problem statement entirely presented systematically, conclude the research's conclusion in the form of a conservation conceptualization model, and revise the community-based conservation model to prevent the environmental crisis. The case study used to recall the limited research time and considered sufficient to explore and describe people's conditions related to the environment and the relationship between agent and structure in the social practice process.

\section{Results and Discussion}

Conservation in the current sense and often translated as the wise use of natural resources (Christanto 2014); therefore, conservation policy and practice should be guided by the best information and adequate conceptual framework. Historically, natural science tends to be the primary information used to guide conservation action. Many influential conservation scientists have recognized the importance of social and natural consideration for conservation, and it has been acceptable commonly that the participation of human dimension in environment conservation and management is required to make healthy and effective conservation policy, either action (process) or output (product) (Bennett et al. 2017). Community conservation (community-based natural resource management) is a transnational attempt to build legitimacy and global support for the community as an appropriate social institution for natural resource conservation. A community conservation program connects rural community development, such as: environmental and sociological concern (Belsky 2002, Western \& Wright 1994).

Conservation cannot be conducted alone; it is a transnational attempt of building strong legitimacy, not only relying on the state's constitution but also needing local regulation and even village regulation. Legitimacy can also be obtained from traditional, charisma, and legal or rational sources (Hermann 1983). Conservation should be supported by all parties, either public (state) or private. Public (community) participation is equally important, both individually and in a group, as a social institution appropriate to natural resource conservation, support from family, education, religion, an apolitical, and cultural institution. Local wisdom is essential because ecological sustainability can only be achieved and created if natural resources are interpreted from economic values alone and given ethical and aesthetic values (Hidayat 2011). The following is a description of the relevance of legitimacy, social institutions, and participation to preserve natural resources. 


\section{Legitimacy in conservation}

Legitimacy is usually related to a legal issue or legislation made and agreed. The attempt of building legitimacy in the conservation field in Indonesia has been included in Republic of Indonesia's Law Number 5 of the Year 1990 about the Conservation of Living Natural Resource and its Ecosystem and Local Regulation about Living Environment Protection and Management at the local level, for example, Malang District Regulation Number 3 of the Year 2016 Concerning Environmental Protection and Management.

Legitimacy established should remain to be supported by local government, called Village Regulation or Peraturan Desa (Perdes) to establish strong legitimacy for the natural resource conservation; however, in this case, it is still conducted rarely at the village level. Although the legitimacy effort has been established, unfortunately, it has not been understood entirely by the general public. It is challenging to implement without the support from activators or local figures active and willing to sacrifice natural resource conservation. According to Ekawati (2012), legitimacy can also be obtained from many sources: traditional, charisma, legal, or rational. Mr. Slamet is the selected one legitimized in the conservation activity practice in Bendrong Village, both charismatically and rationally. Mr. Slamet is considered a leader with a vision and mission that can inspire and provoke the people through his activity, and rationally Mr. Slamet was appointed to be the Head of Farmer Group. On $12^{\text {th }}$ June 2013, Mr. Slamet was crowned to be an environmental rescuer and successfully brought Kalpataru given by President Susilo Bambang Yudhoyono. Kalpataru is an award given to an individual or group for conserving the living environment in Indonesia.

\section{Local wisdom in conservation activity}

In Indonesia, local wisdom plays an essential role in balancing its dominance in development activities toward its policy instruments (Huruta \& Kurniasari 2018). Local wisdom is built from social values that are upheld in the social structure of the community itself and have a function as a guide, controller, and signs for behavior in various dimensions of life when dealing with others and also with nature (Ariyanto et al. 2014). As Aulia \& Darmawan mentioned, the function of local wisdom is for the conservation and preservation of natural resources (Maridi 2015). Local wisdom can be in the form of local knowledge, local skills, local resources, local social processes, local values or norms, and local customs (Niman 2019). As in the Bendrong Hamlet, local wisdom applies in conservation activities. Empowerment of local wisdom is an effective way to realize that humans must make friends with nature because of their interdependence. This principle limits the exploitation of nature by taking into account environmental conservation (Mumpuni et al. 2015).

The form of local wisdom held is held annually in Bendrong Hamlet, in Suro month, which is Muharram in the Islamic calendar. In this month, there are many essential agendas in Javanese culture, so that many festivals or celebrations are held intended for religious, cultural, and environmental activities for conserving Javanese tradition in particular. Similarly, village cleaning or bersih desa activity is held annually in Suro at Bendrong Hamlet; other activities are building green week activity, cleaning the river, preparing biogas, conservation carnival, and problems raised to be solved. Other activities are conservation fragment, conservation film production, water source rite (slametan), and tree planting. The village cleaning activity held annually involves the village elder (dukun desa) to lead water source rite (slametan mata air) involving the existing art, such as infertile fly attraction (terbang gandul attraction) and cangkrukan activity discussing a variety of problems including environmental issues. Conservation activities involving local wisdom carried out once a year, meaning that local wisdom values have not been applied in daily activities, and it can be said that local wisdom is still weak in the community. Considering that the position of local wisdom is currently in a weak position (Thamrin 2013), for this reason, community participation is needed to maintain local wisdom in its function of preserving natural resources. 


\section{Public participation in conservation activity}

In general, conservation is wise management of resources to ensure the sustainability of their supply while maintaining and improving the quality of values (Sudarmadji et al.2011), while the community's active participation is the key to the success of conservation. According to Sinery \& Manusawai (2016), much conservation area management is unsuccessful due to differences in understanding of the basic concept of conservation, which accommodates people's desire to manage natural resources in an area. Apart from being one of the fundamental aspects of a democratic system (Hermawan \& Hutagalung 2019), participation is also essential in conservation activities. Prasmaningrum (2010) defined participation as community interaction in the planning or decision-making process, implementing the decision, enjoying, and following the results. Types of community participation in conservation can be in the form of participation of ideas, participation of labor, participation of assets, participation of skills and skills, and social participation (Mulyanie 2016).

All people of Bendrong Hamlet support the conservation activity undertaken. Those involved in conservation activities, in addition to Mr. Slamet (head of the farmer group), are all citizens of Bendrong Hamlet, participating either individually or in groups by establishing such groups as Taruna Tani (connecting farmer sector), Paguyuban Bakti Manunggal (PBM) for the not-married youth group, Kelompok Perempuan Peduli Lingkungan (KPPL) consisting of women operating in the rubbish sector, and Female Farmer Group, expectedly to motivate the men to participate actively in conservation activity, particularly yard land utilization. People conduct conservation activity as a form of social practice expected to give them comfort. Conservation activity developed from the motivation of local wisdom values focusing on environmental conservation.

Bendrong Hamlet acquired conservation knowledge from field school education held by the Environmental Services Program (ESP) Non-Governmental Organization. ESP provides facilities for the field school, including transportation, residence, and consumption. Having attended the field school, they are required to prepare the pioneering action as a field school product by solving a problem existing in the village, and then the knowledge acquired from field school is practiced. ESP helps provide $20 \%$ of the pioneering action activity cost, and the rest of the cost obtain from the community self-help fund. Having prepared pioneering action as the product of field schooling given by ESP, the people of Bendrong Hamlet established the Farmer Group; after that, it socialized through the meetings held within Bendrong Hamlet, such as recurring tahlilan events. Members of USAID (United States Agency for International Development) from America visited Bendrong Hamlet directly in August 2008.

The people wanted to establish self-sufficient energy in biogas, with 25 biogas units being the target established using a community self-help system, officially announced and socialized. Cost problems inhibited the program. They eventually looked for a bailout and obtained it from Paramitra NonGovernmental Organization to help the people build biogas units, with an installment system of the harvest payment strategy, recalling that most Bendong Hamlet people are farmers. The target would not be achieved without funding; until late 2008, the target could not be achieved, and only five biogas units could be built: four resulting from self-help fund and one from local government's help. After that, people conducted an evaluation on the constraint encountered, in this case, the fund, because the biogas development cost is costly, so that an initiative appeared to establish Arisan Biogas to buy biogas development material. At the same time, the work done by the hamlet people in a cooperation scheme.

The fund derives from two sources: Arisan Biogas and bailout from Paramitra Non-Governmental Organization, called yarnen (repayment in harvest period). When the project was halfway (the first six months), the Malang Regent came to the hamlet to offer help in the form of a partnership program. The local government provided plastic biogas units at 2.750 IDR price per unit. A stimulant of 275.000 IDR give, and the rest derived from the community self-help fund. The partnership with the local government successfully constructed 260 biogas units, for which a proposal failed to obtain an 
Energy Self-Sufficient Award to Ministry of Human Resource and an Energi Prakarsa Award obtain in 2011. Conservation activity successfully is undertaken due to the agent, Mr. Slamet, legitimized and supported by the community; with various activity structures undertaken, a social practice of environment conservation established.

\section{Natural resource conservation effort in Bendrong Hamlet}

The concept of preservation and utilization of natural resources, in general, has two main things: First, to ensure the preservation of quality in terms of being productive, reactive, and aesthetic. Second, to preserve the results and use of natural resources to continue to produce for a long time. Thus, this concept focuses on establishing a harmonious relationship between the needs of human life and natural resources (Fauzi 2004). As has been implemented in Bendrong Hamlet, the community carries out several conservation activities to preserve the environment. Bendrong Hamlet is more known as a conservation and energy self-sufficient village. It is a conservation village because it successfully undertakes people's forest conservation activity and is an energy self-sufficient village due to Mr. Slamet's cold guiding hand, in which cow manure, usually disposed of, can now be changed into biogas as alternative energy. Two conservation activities occur in Bendrong Hamlet: green conservation and energy conservation.

Green conservation is agroforestry-based conservation. Agroforestry is a spatial land-use system carried out by humans by applying various existing technologies through the use of seasonal crops, annual crops, and forage plants at the same time or taking turns in a certain period so that ecological, social, and economic interactions are formed in them (Rendra et al. 2016). According to Suryani \& Dariah (2012), agroforestry systems act as soil conservation measures to avoid and overcome land degradation and sustainable land use by creating land cover agroforestry vegetation that protects soil and erosion. Agroforestry-based conservation that is carried out in Bendrong Hamlet is by planting forest wood, especially in an inclined area, handling critical forests, areas prone to landslides, deforested forests with forestry plants underneath, planting agroforestry for flat land, as well as building terraces, build a water barrier (galiplak/anggel) with the hope that the eroded mud will be retained, and flood barrier. By carrying out green conservation, the people of Bendrong Hamlet hope to avoid land degradation and to increase the community's economy through agroforestry-based conservation.

Energy conservation conduct by processing the cow manure, usually disposed of, into biogas as alternative energy utilized as the people's primary fuel. According to the farmer group of Bendrong Hamlet, the use of biogas exerts a sufficiently positive effect. First, ecological effect; HouseholdScale Biogas or Biogas Skala Rumah Tangga (BSRT) with a gas storage volume of $2 \mathrm{~m}^{3}$ gas capacity can substitute for fuelwood for the cooking need at household scale; thus, when there are 300 Household-Scale Biogas units in biogas kampong, automatically 1.500 trees will be saved annually, and the people's pressure against the forest will decrease in the presence of biogas. Second, economic effect; the average price of fuelwood in the rural area is $20.000 \mathrm{IDR}$ per one shoulder $(137 \mathrm{lbs})$ and can fulfill the cooking need for four days only, so those who could not look for fuelwood should spend 5.000 IDR per day or 1.800.000 IDR per year. Biogas Kampong with 300 BSRT units will help save 540.000.000 IDR per year; moreover, it also saves the use of fossil energy. It means that Biogas Kampong can help relieve the government's burden on fuel subsidy. Third, social effect; to get both fossil and traditional energies, human beings encounter some conflicts, either with government or between fellow human beings or animals; thus, life welfare and harmonious quality of life are difficult to achieve. Biogas Kampong will reduce the potential conflict occurring in humanity's life with the energy self-sufficient concept. This energy self-sufficiency expects to affect Biogas Kampong to achieve food and water self-sufficiency positively.

The flow of capitalism dominates in the joints of community life; in the view of capitalism, the analysis of profit and loss is more dominant and more important than from where the source of knowledge comes (Thamrin 2013). Therefore, the impact of conservation activities must also be considered in the sustainability of conservation activities. As in Bendrong Hamlet, conservation activities' success cannot be separated from the various impacts that have been generated, ranging from the ecological, social, and economic impacts as described above. The success of conservation 
activities has a critical urgency, both from an economic point of view and a socio-philosophical perspective, based on a socio-economic perspective. It will improve human life quality, increase human moral responsibility life, and preserve cultural heritage (Rachman 2012). Based on the result and discussion of the research, the existing community-based environmental conservation model that exists in the conservation and energy independent village in Bendrong described in Figure 1.

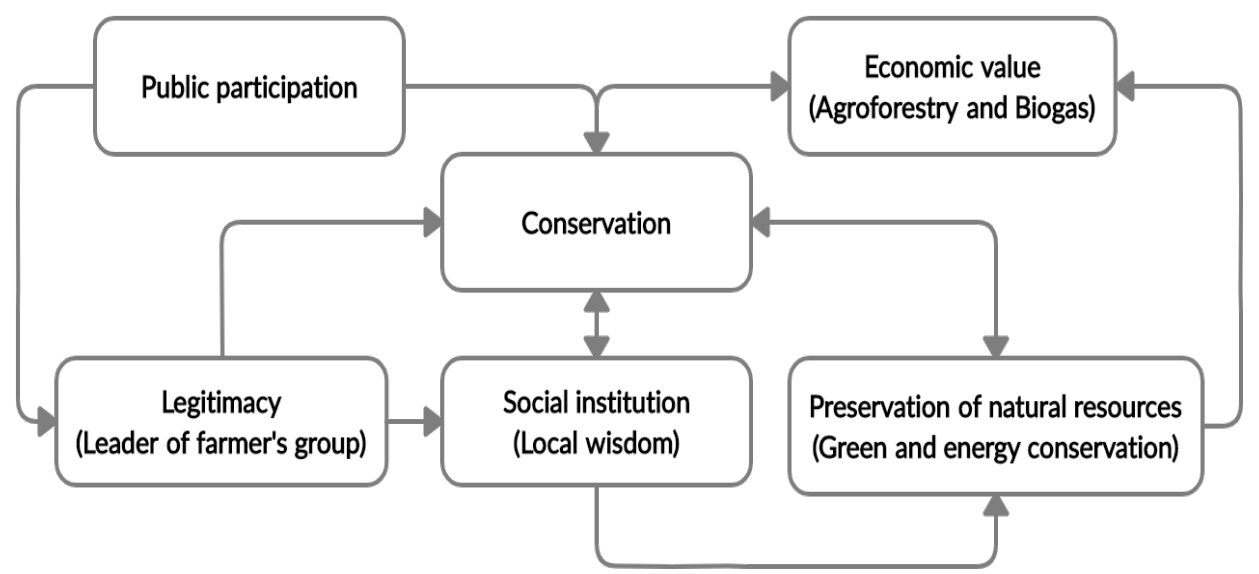

Figure 1.

Existing model of community-based conservation in Bendrong Hamlet

The conservation model based on community, which has been implemented in Bendrong Hamlet, is conservation in two forms of activities, green conservation, and energy conservation. Green conservation is the conservation of community forests to plant trees and plant agroforestry plants underneath. In contrast, energy conservation makes cow dung, usually wasted, converted into biogas as alternative energy, which is the primary fuel for residents. From the two activities, it produces an economic value which is quite beneficial for the community of Bendrong Hamlet. These activities cannot be separated from community participation led by the head of a farmer group who has been legitimatized as a leader in conservation activities and the support of social institutions by applying local wisdom values that direct in conservation activities. In essence, conservation runs thanks to community participation, the involvement of legitimacy, local wisdom, and impacts resulting from efforts to conserve natural resources such as ecological, social, and economic impacts.

\section{Conclusion}

The implementation of conservation activity is inseparable from the supporting factors, such as public participation, supporting legitimacy, the social institution involved, and national resourceconserving attempt. Mr. Slamet is selected to be legitimized in implementing conservation activity in Bendrong Hamlet, both charismatically and rationally. The form of local wisdom in Bendrong Hamlet is held annually in Suro month through village cleaning (bersih desa) activity with a series of activities including establishing green week activity, cleaning the river, preparing biogas, holding conservation carnival, conservation fragment, water source rite (slametan mata air), planting trees, and cangkrukan activity discussing various problems, including environmental issues. Everyone living in Bendrong Hamlet is required to participate in conservation activity, either individually or in social groups such as farmer group: Taruna Tani, Paguyuban Bakti Manunggal (PBM), Kelompok Perempuan Peduli Lingkungan (KPPL), and Kelompok Tani Wanita.

Environment conservation conducted in Bendrong Hamlet is divided into two activities: green conservation and energy conservation. In addition to being an environmental factor, the conservation activity serves to support economic factors as well, obtained from green conservation and energy conservation activities. Social institutions' participation, legitimacy, and government, private, and community's participation, either individually or in the group, are essential to the performance of conservation activity as the attempt of conserving natural resource; also, economic activity should be included in the conservation activity in order to result in an effective and sustainable community conservation activity. 


\section{References}

Ariyanto, Imran R, \& Toknok B (2014) Kearifan masyarakat lokal dalam pengelolaan hutan di Desa Rano Kecamatan Balaesang Tanjung Kabupaten Donggala. Jurnal Warta Rimba 2 (2):84-91.

Balai Penanggulangan Bencana Daerah (2017) Menutup tahun 2017, kerugian akibat bencana tembus 6 M. [Accessed 16 February 2018]. https://bpbd.malangkota.go.id/2017/12/31/menutuptahun-2017-kerugian-akibat-bencana-tembus-6-m/.

Belsky JM (2002) Beyond the natural resource and environmental sociology divide: Insights from atransdisciplinary perspective. Society and Natural Resources 15 (3):269-280. https://doi. org/10.1080/089419202753445106.

Bennett NJ, Roth R, Klain SC, Chan K, Christie P, Clark DA, Cullman G, Curran D, Durbin TJ, Epstein G, Greenberg A, Nelson MP, Sandlos J, Stedman R, Teel TL, Thomas R, Verissimo D, \& Wyborn C (2017) Conservation social science: Understanding and integrating human dimensions to improve conservation. Biological Conservation 205 (2017):93-108. https:// doi.org/10.1016/j.biocon.2016.10.006.

Ekawati EN (2012) Legitimasi politik pemerintah desa (Studi pengunduran diri kepala desa di Desa Cindai Alus Kecamatan Martapura Kabupaten Banjar). Jurnal Ilmu Politik dan Pemerintahan Lokal 1 (2):58-72.

Fauzi A (2004) Ekonomi Sumberdaya Alam dan Lingkungan. Jakarta: Gramedia Pustaka Utama.

Hakim AL \& Wienarto N (2010) Pengelolaan Sumber Daya Alam dan Lingkungan Das Brantas Hulu. In: Suradisastra K et al. (eds). Membalik Kecenderungan Degradasi Sumber Daya Lahan dan Air. Bogor: IPB Press.

Hermann DH (1983) Max Weber and the concept of legitimacy in contemporary jurisprudence. DePaul Law Review 33 (1):1-29.

Maridi (2015) Mengangkat budaya dan kearifan lokal dalam sistem konservasi tanah dan air. In: Seminar Nasional XII Pendidikan Biologi FKIP UNS 2015, 8 August, Surakarta.

Nana (2017) 2017, Longsor dominasi bencana alam di Kabupaten Malang. Malang Times, 22 December. [Accessed 16 February 2018]. https://www.malangtimes.com/baca/23527/ 20171222/230333/2017-longsor-dominasi-bencana-alam-di-kabupaten-malang.

Niman EM (2019) Kearifan lokal dan upaya pelestarian lingkungan alam. Jurnal Pendidikan dan Kebudayaan Missio 11 (1):91-106.

Prasmaningrum H (2010) Kajian partisipasi masyarakat dalam pengembangan pariwisata alam kawasan Plawangan-Turgo Taman Nasional Gunung Merapi. Thesis, Universitas Gadjah Mada, Yogyakarta.

Prodanciuc R (2012) Social institutions. Annals of the University of Petroşani, Economics 12 (2):236-243.

Sudarmadji S, Suprayogi S, Widyastuti M, \& Harini R (2011) Konservasi mata air berbasis masyarakat di unit fisiografi Pegunungan Baturagung, Ledok Wonosari dan Perbukitan Karst Gunung Sewu, Kabupaten Gunung Kidul. Jurnal Tekno Sains 1 (1):42-53. https://doi.org/10.22146/ teknosains.3990.

Sudiasmo F (2017) Nilai-nilai Islam dalam konstruksi sosial konservasi lingkungan pesisir (Studi di Mangrove Center Tuban). Jurnal Satwika 1 (1):14-27. https://doi.org/10.22219/SATWIKA. Vol1.No1.14-27.

Sugiyono (2008) Metode Penelitian Kuantitatif Kualitatif dan R \& D. Bandung: CV Alvabeta.

Thamrin H (2013) Kearifan lokal dalam pelestarian lingkungan. Jurnal Kutubkhanah 16 (1):46-59.

Wardani NK (2017) Memadukan religi, budaya dan konservasi: Belajar konservasi dari Desa Penyangga TN Bromo Tengger Semeru. [Accessed 9 January 2018]. http://ksdae.menlhk. go.id/berita/2271/memadukan-religi,-budaya-dan-konservasi-:-belajar-konservasi-daridesa-penyangga-tn-bromo-tengger-semeru.html. 